\title{
External iliac artery pseudo-stenosis associated with catheterization: report of two cases
}

Rzekome zwężenie tętnicy biodrowej zewnętrznej związane z cewnikowaniem: opis dwóch przypadków

\author{
Hekim Karapınar¹, Ibrahim Gül'1, Zekeriya Küçükdurmaz¹, Hasan Ali Gümrükçüoğlu², Ahmet Yılmaz \\ 1Department of Cardiology, Cumhuriyet University, Medical Faculty, Sivas, Turkey \\ 2Department of Cardiology, Yüzüncüyıl University, Medical Faculty, Van, Turkey
}

Postep Kardiol Inter 2012; 8, 4 (30): 360-362

DOI: 10.5114/pwki.2012.31921

\begin{abstract}
In invasive cardiology practices, the most commonly used vascular access site is the femoral artery. Atherosclerotic stenoses on the femoral and iliac arteries create difficulties in these practices. Vasospasm rarely occurs on large arteries like these. This paper reports stenosis encountered during coronary angiography on iliac arteries in 2 patients. The stenoses caused difficulties for guidewire and catheter insertion in catheterization. In the revisualization of these arteries at the next session, the stenoses had disappeared, but the arteries were tortuous. The patients did not have peripheral ischemia signs previously, nor did they appear after the procedure. These transient stenoses might have occurred due to vasospasm and the accordion effects caused by the guidewire and/or catheter.
\end{abstract}

Key words: iliac artery, catheterization, stenosis

\section{Streszczenie}

Dostęp od tętnicy udowej jest najczęściej używanym dostępem naczyniowym w kardiologii interwencyjnej. W związku z tym miażdżyca tętnic udowych i biodrowych powoduje utrudnienia w przeprowadzeniu zabiegu. W przypadku tego typu dużych tętnic rzadko jednak dochodzi do ich obkurczenia. W poniższym doniesieniu opisano zwężenie tętnic biodrowych stwierdzone w trakcie koronarografii u 2 pacjentów. Zwężenia utrudniły przeprowadzenie prowadnika i cewników do koronarografii. Podczas obrazowania tych tętnic w trakcie kolejnych zabiegów okazało się, że zwężenia zniknęły, ale tętnice miały kręty przebieg. Zarówno przed zabiegiem, jak i po nim pacjenci nie zgłaszali objawów niedokrwienia kończyn dolnych. Obserwowane zwężenia mogły być efektem skurczu tętnic i wystąpienia objawu akordeonowego spowodowanego przez prowadnik i/lub cewnik.

Słowa kluczowe: tętnica biodrowa, cewnikowanie, zwężenie

\section{Introduction}

Spasm of small arteries such as the coronary or radial artery is well described and observed as a usual state in practice. But spasm of large arteries such as the femoral or iliac artery is an unexpected condition. This situation may cause difficulties to access the artery, or may be responsible for unnecessary interventions.

We report two cases of pseudo-stenosis of the external iliac artery related to catheterization.

\section{Case reports}

\section{Case 1}

A 51-year-old patient with acute anterior myocardial infarction was taken to the catheter laboratory for primary percutaneous coronary intervention. Resistance was sensed at the iliac artery level but crossed successfully with a 0.038 inch guide-wire. Coronary angiography revealed subtotal occlusion of the left anterior descending artery. Peripheral angiography was performed after the success- 


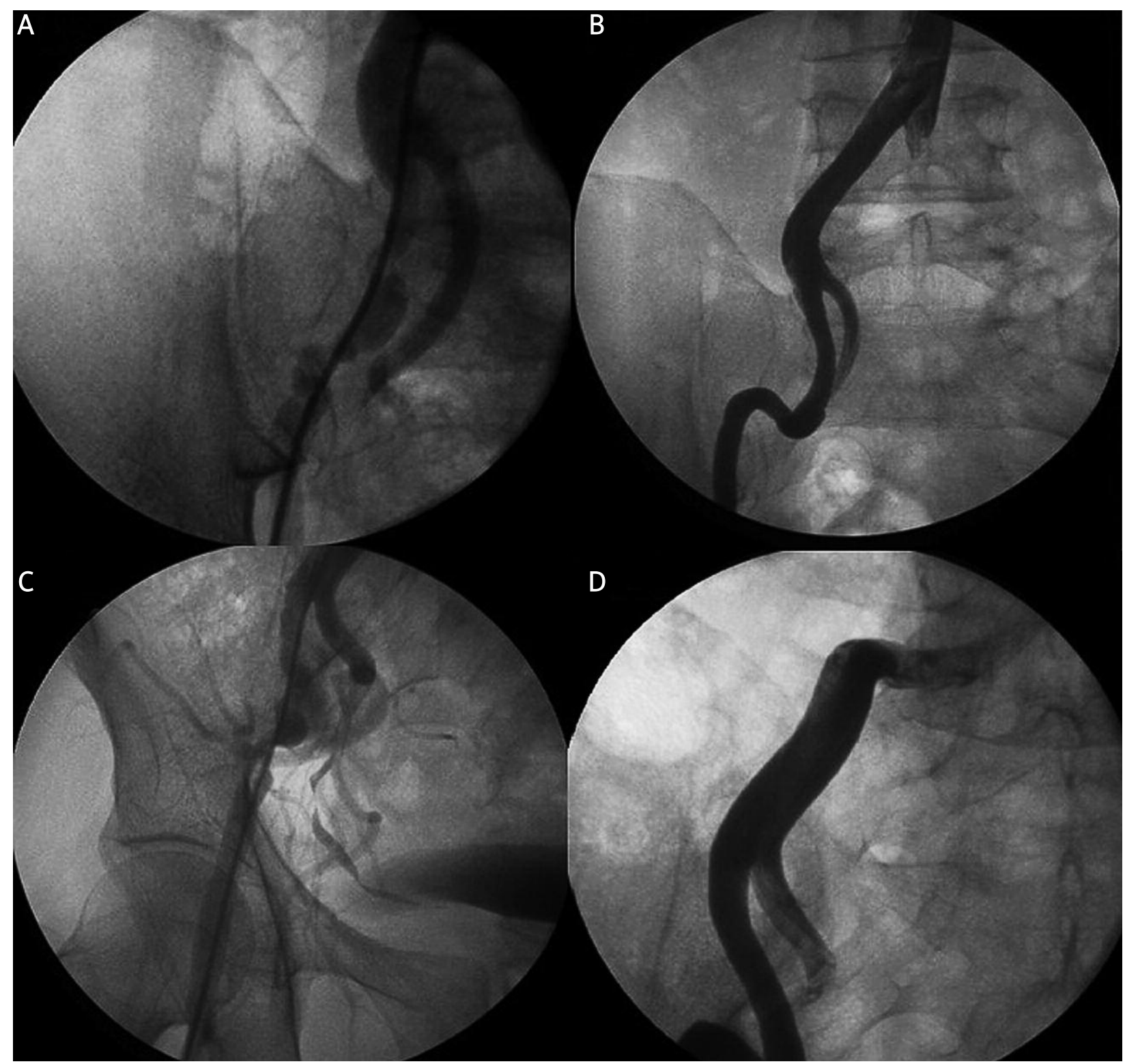

Fig. 1. Multiple significant stenoses are seen at the right external iliac arteries (A, C). Stenoses are not visible when arteries are visualized without the catheter (B, D)

Ryc. 1. Wiele istotnych zwężeń widocznych w prawej tętnicy biodrowej zewnętrznej $(A, C)$. Zwężenia zniknęty po usunięciu cewnika $(B, D)$

ful coronary intervention. High-grade tandem stenoses were seen at the right external iliac artery (Fig. 1 A). The patient was considered for iliac artery stent implantation. But he had no history of claudication or ischemiarelated signs and the intervention was cancelled. Control angiography was performed before guidewire advancement at the next session. Just a non-critical lesion and tortuosity were found at the external iliac artery (Fig. 1 B).

\section{Case 2}

A 55-year-old man suffering from stable angina pectoris was referred to our hospital for elective coronary angiography. Resistance was sensed at the iliac artery dur- ing the crossing of a 0.038 inch guide wire. Coronary angiography revealed only non-critical atherosclerotic disease; but peripheral angiography revealed a significant right external iliac artery stenosis (Fig. $1 \mathrm{C}$ ). The patient was considered for iliac stenting at another session. But the patient had neither claudication nor ischemia-related findings. At the next session, after an introducer sheath had been placed, angiography was performed again. But no lesion appeared at the iliac artery (Fig. 1 D).

\section{Discussion}

Peripheral arterial interventions are performed more extensively by cardiologists day by day. High success rates 
have been reported and these results give hope to cardiologists [1, 2]. Sometimes cardiologists diagnose peripheral artery disease during diagnostic or interventional catheterization. Unexpectedly diagnosed significant limb artery lesions, especially in the case of acute coronary syndrome, sometimes make the physician neglect the symptoms of patients associated with peripheral artery disease due to the visually seen "significant lesion". Catheter-induced vasospasm is a familiar phenomenon for invasive cardiologists. This condition may mimic lesions in coronary and small peripheral arteries [3]. Another condition which causes pseudo-stenosis imaging is called the "accordion effect". This condition occurs due to wire straightening or a folding effect of wire in the tortuous vessels. This phenomenon is seen especially at the right coronary artery when an extra support guide wire is used [4]. This image may be seen theoretically in all sizes of vessels. But the accordion effect at the large arteries such as the iliac artery has rarely been reported [5-9]. Implementations of diagnostic and interventional peripheral catheterization by cardiologists are becoming widespread. Hence unawareness of these conditions may cause unnecessary peripheral interventions. Considering vasospasm and the accordion effect phenomenon may be helpful in novel, unexplained stenotic situations without any symptom or complaint.

\section{References}

1. Bartuś S, Siudak Z, Brzeziński M, et al. Percutaneous peripheral interventions in patients with non-ST elevation acute coronary syndromes by interventional cardiologists: rationale and results. Kardiol Pol 2008; 66: 135-141.

2. Bartuś S, Siudak Z, Chyrchel M, et al. Long-term follow-up of percutaneous peripheral interventions in lower limb arteries in patients with acute coronary syndrome and diabetes. Post Kardiol Interw 2010; 6: 117-121.

3. Zanchetta M, Pedon L, Rigatelli G, et al. Pseudo-lesion of internal mammary artery graft and left anterior descending artery during percutaneous transluminal angioplasty - a case report. Angiology 2004; 55: 459-462.

4. Shea PJ. Mechanical right coronary artery shortening and vessel wall invagination: a fourth cause of iatrogenic coronary obstruction during coronary angioplasty. A case report and review of the literature. Cathet Cardiovasc Diagn 1992; 26: 136-139.

5. Joseph D, Idris M. Catheter-induced "accordion effect" in tortuous right external iliac artery during peripheral angiography. Cathet Cardiovasc Diagn 1995; 34: 318-320.

6. Gallagher C, Shanklin C, Roonsritong C, et al. Bilateral external iliac artery catheter-induced vasospasm during angiography: a case report. Angiology 2006; 57: 115-118.

7. Trani C, Biondi-Zoccai GG, Burzotta F, et al. Catheter-induced straightening of external iliac tortuosity: a cause of pseudostenosis to be borne in mind. Int J Cardiol 2005; 101: 333-334.

8. Shortal BP, Mahmud E, Tsimikas S. Catheter-induced vasospasm of both the right external iliac and right coronary arteries during coronary angiography. Int J Cardiovasc Imaging 2005; 21: 481-485.

9. Ergene O, Tastan A, Seyithanoglu Y, et al. Catheter-induced vasospasm in the right external iliac and femoral arteries during a cardiac diagnostic procedure. Int J Card Imaging 1999; 15: 189-193. 